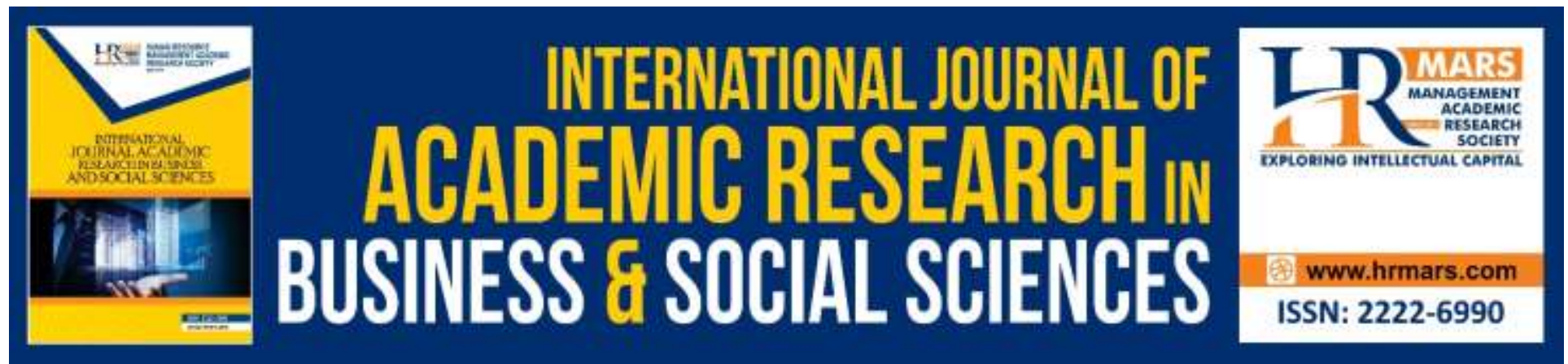

\title{
The Impact of Tax Ethics and Knowledge on Tax Compliance among Palestinian Taxpayers
}

Amjad Abdallah Alkhatib, Mohammad Ziad Hamad, Majed Daleel Hermas

To Link this Article: http://dx.doi.org/10.6007/IJARBSS/v10-i6/7305

DOI:10.6007/IJARBSS/v10-i6/7305

Received: 26 March 2020, Revised: 29 April 2020, Accepted: 29 May 2020

Published Online: 25 June 2020

In-Text Citation: (Alkhatib et al., 2020)

To Cite this Article:Alkhatib, A. A., Hamad, M. Z., \& Hermas, M. D. (2020). The Impact of Tax Ethics and Knowledge on Tax Compliance among Palestinian Taxpayers. International Journal of Academic Research in Business and Social Sciences, 10(6), 346-352.

Copyright: (C) 2020 The Author(s)

Published by Human Resource Management Academic Research Society (www.hrmars.com)

This article is published under the Creative Commons Attribution (CC BY 4.0) license. Anyone may reproduce, distribute, translate and create derivative works of this article (for both commercial and non-commercial purposes), subject to full attribution to the original publication and authors. The full terms of this license may be seen at: http://creativecommons.org/licences/by/4.0/legalcode

Vol. 10, No. 6, 2020, Pg. 346 - 352

Full Terms \& Conditions of access and use can be found at http://hrmars.com/index.php/pages/detail/publication-ethics 


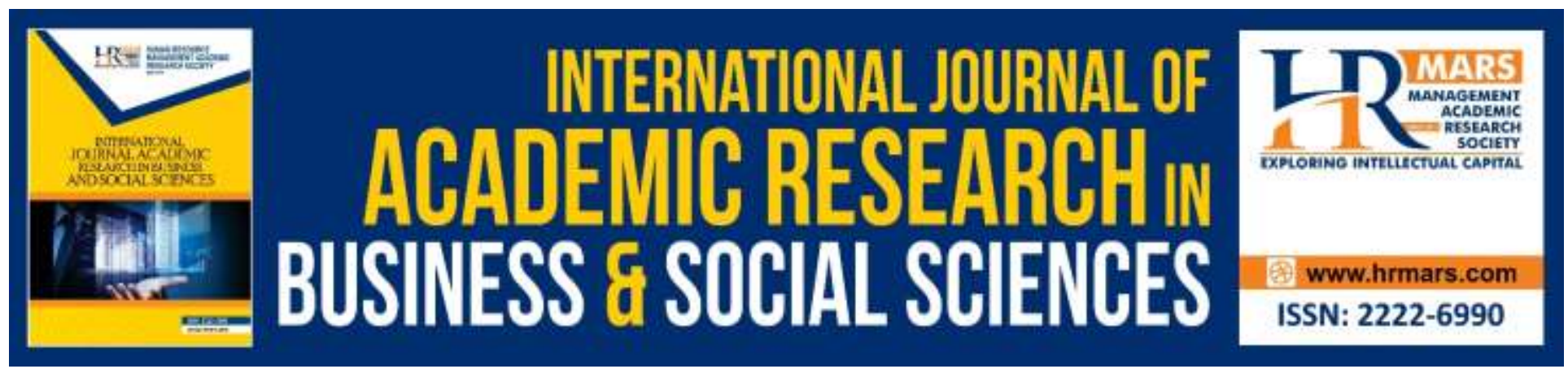

\title{
The Impact of Tax Ethics and Knowledge on Tax Compliance among Palestinian Taxpayers
}

\author{
Amjad Abdallah Alkhatib¹, Mohammad Ziad Hamad², Majed \\ Daleel Hermas ${ }^{3}$ \\ ${ }^{1}$ Department of Accounting, Palestine Ahliya University, ${ }^{2}$ Department of Accounting, Palestine \\ Ahliya University, ${ }^{3}$ Department of Accounting, Palestine Ahliya University, \\ Email:amjad@paluniv.edu.ps, Mohammadzhamad97@gmail.com, \\ Majed_H_1997@hotmail.com
}

\begin{abstract}
Tax compliance is an ongoing challenge for policymakers worldwide. As the tax is the most important financial resource for governments to finance their public expenditures. Especially, in countries such as Palestine due to a lack of natural resources. So tax evasion and avoidance have a significant negative impact on the government to meet their obligations, as the public budget of Palestine is largely dependent on tax revenues that constitute $90 \%$ of the public budget going forward with its obligations to society. Good tax administration and efficient tax collection is a prerequisite for securing adequate tax returns. The current study focuses on identifying the role of tax knowledge and tax ethics on tax compliance among Palestinian taxpayers. The current study is designed on the basis of a review of previous studies on tax knowledge and ethics with tax compliance and its impact on tax revenues. Tax non-compliance is one of the tax and financial phenomena that studies and statistics confirm are common in all countries of the world, but in proportions that differ from one country to another, and from a period of time to another.
\end{abstract}

Keywords: Tax Compliance, Tax Ethics, Tax Knowledge.

\section{Introduction}

Tax revenue is one of the oldest ways to provide the funds needed for government sustainability, and most economies rely on taxes to meet spending needs (Alkhatib et al., 2019; Alshrouf, 2019; Kira, 2017). As taxes are an important source of income for the state, they increase public treasury revenues. One of the countries' policies is to impose taxes in order to achieve stability and economic growth (Abuamria, 2019). On the other hand, some see it as helping to stabilize social, income redistribution among the different classes of society. However, many countries around the world, whether developed or developing, suffer from a high rate of non-compliance, as there is no $100 \%$ compliance by taxpayers in the performance of their tax obligation (Alkhatib et al., 2018; Alleyne \& Harris, 2017). Tax non-compliance is a global phenomenon and causes major losses in government revenue. 
And the failure to provide the tax amounts due to the taxpayers necessarily means that there is a financial gap in the budgets of countries, as the amounts collected from taxes are usually spent in support of societal activities and infrastructure in the state, and the risk of noncompliance is that the amounts that are not commitment to pay it is relatively large, as a specialized government economic reports in the worlds confirmed that tax non-compliance costs the world public treasury annual losses billions dollars, at a time when the governments continues to implement its austerity policy with the aim of reducing the Public debt.

Tax non-compliance in Palestine, which is considered one of the developing countries, poses a danger to government income, as it suffers greatly from tax non-compliance, where the Integrity and Accountability Alliance in Palestine estimated that $\$ 500$ million was the annual loss of the Palestinian treasury due to lack of tax compliance (Alkhatib et al., 2019; Coalition for Accountability and Integrity, 2018). Many researchers believe that there are several reasons that encourage tax compliance, including reasons that go back to the taxpayer himself and are reflected in the strength of the moral level and tax knowledge. The present study will assist the competent authorities in identifying these factors in order to work to understand them and help to encourage tax compliance for taxpayer.

\section{Literature Review and Hypothesis Development Tax Ethics and Tax Compliance}

Ethics imply a moral mind-set which directs the human actions as well as businesses, and shapes a part of the attitude related to the behaviours of people (Al Zeer et al., 2019). Tax morality is defined as the degree of national and cultural awareness prevailing in the state; and so the higher this level among individuals, the more these individuals enjoy a high sense of tax responsibility, and growing love for the public interest, and a relentless pursuit towards performing their duties, which are determined based on the laws and regulations (Torgler \& Schneider, 2009). Among those regulations comes in the first place accepting them to fulfill their tax obligation, as this is one of the methods to preserve the entity of the state and contribute to its progress and advancement, and even help it to provide the best services to all members of society, in light of that very few researchers discussed taxes from the ethical aspects.

A different approach of tax compliance ethics was found in a study made by Harun et al. (2011), which compared the perception of accounting and business students at a local university in Malaysia. The study found that accounting students thought that non-compliance with tax regulations wasn't ethical, while business students believed that non-tax compliance could be both ethical and unethical according to the circumstances .

This economic crime brings harmful effects on society because it gradually reduces people's confidence in the tax system. Tax compliance behavior also depends on taxpayer perceptions of other people's behavior (Alm \& Torgler, 2011). This means that the ethical obligation to comply with tax compliance depends on the ethical behavior, values, and ethical attitudes of other taxpayers according to Nhavira (2016). It is clear that the social-ethical view assumes that taxpayers make their decisions which are related to paying taxes on their ethical beliefs, on the other hand, and from a rational point of view, one can say that self-interest maximization is the primary driver of tax noncompliance. Many current studies have found that the relationship between ethics and tax compliance is positive. Social norms are closely related 
to the culture of paying taxes. These standards tend to encourage voluntary compliance, which causes citizens to collaborate with their government when compliance is considered positive and socially desirable (Frey \& Torgler, 2007). These dimensions are especially important for developing countries to consider, as they have limited funds and infrastructure to levy taxes.

McGee and Tyler (2006) noted that students in Korea, Japan, and China found that the level of ethics had a significant positive correlation with the tax compliance process, as it stated that higher-educated students were less tempted to process non-compliance actions, while at the lower educational level they had a greater tendency to oppose taxes. One possible justification for this is that graduate students generally are older and more mature than undergraduate students, add that older citizens are more aware of the consequences if they don't intentionally comply with taxes.

Based on the above, most previous studies indicated that the relationship is positive between tax ethics and tax compliance (Alm \& Torgler, 2011; Chan et al., 2000; Frey \& Torgler, 2007; Riahi-Belkaoui, 2004), other studies have found that the relationship between them is either negative or that there is no relationship at all (Ariel, 2012; Slehat, 2009). Thus, the current study proposes the followings:

\section{H1: There is a positive relationship between tax ethics and tax compliance.}

\section{Tax Knowledge and Tax Compliance}

Knowledge is known or recognized information, knowledge is something known to be associated with the learning process, and tax knowledge in general is the ability to understand basic tax concepts applied within a country (Alkhatib \& Abdul-Jabbar, 2017). Understanding tax policies by taxpayers helps in accepting the tax system and increasing compliance. Tax knowledge is an essential component of voluntary compliance, especially in determining accurate tax commitment. The Edward and Ambrose (2017) study confirmed that taxpayers lack confidence in their ability to calculate the tax owed correctly, which forced them to hire experts in order to prepare the tax return and submit it to the tax authorities. The study concluded that the technical and cognitive skill in filing tax returns is a factor affecting tax compliance. The learning process is influenced by various internal factors such as motivation, and other external factors such as the available information means as well as the proposed social and cultural conditions. Without any tax knowledge, taxpayers intend not to comply with the tax regulations with or without intent. As many tax laws and their existing changes usually pay taxpayers for non-compliance with taxes. The more sophisticated the tax system, the higher the cost of compliance.

Kasper et al. (2013) claims that tax sophistication produces a negative paradigm toward current tax law, which reduces the desire for tax compliance, and the relationship between both tax knowledge and tax compliance is positive. That is, the greater the tax knowledge of the taxpayer, the greater the tax compliance, and this reflects positively on the state treasury.

Tax knowledge is, therefore, one of the most influencing factors in determining taxpayer compliance behavior under the self-assessment system. This was established and supported experimentally by many other studies that include those who have documented that possession of tax knowledge will increase compliance rates. One measure to increase voluntary compliance is to ensure that taxpayers have a certain level of qualifications, ability, and confidence to exercise their tax liability. According to Oladipupo and Obazee (2016) the level of education is an 
important factor affecting tax knowledge. They claim that people with a higher educational level can easily understand the tax requirements. Based on the above, some studies have found that the relationship between tax knowledge and tax compliance is a positive relationship (Eriksen \& Fallan, 1996; Kasper et al., 2013; Oladipupo \& Obazee, 2016), and a number of other studies have found that the relationship is negative or no relationship (Chan et al., 2000; Manual \& Xin, 2016). Thus the relationship between the level of tax knowledge and tax compliance is somewhat mixed, so the present study assumed the following:

H2: There is a positive relationship between the level of tax knowledge and tax compliance.

\section{Research Framework}

The study model presented in Figure 1 below has been developed based on the Social Influence Theory. The theory indicates that social behavior and its impact on decision-making is affected by the surrounding environment. According to the social influence theory, individuals with tax morals and Knowledege are more committed to laws and regulations. In other words, the theory of social influence claims that others intentionally or unintentionally influence the individual's behaviour in the environment, and such behaviour is explained by the relationship of the continuous common interaction between cognitive and behavioural environmental influences.

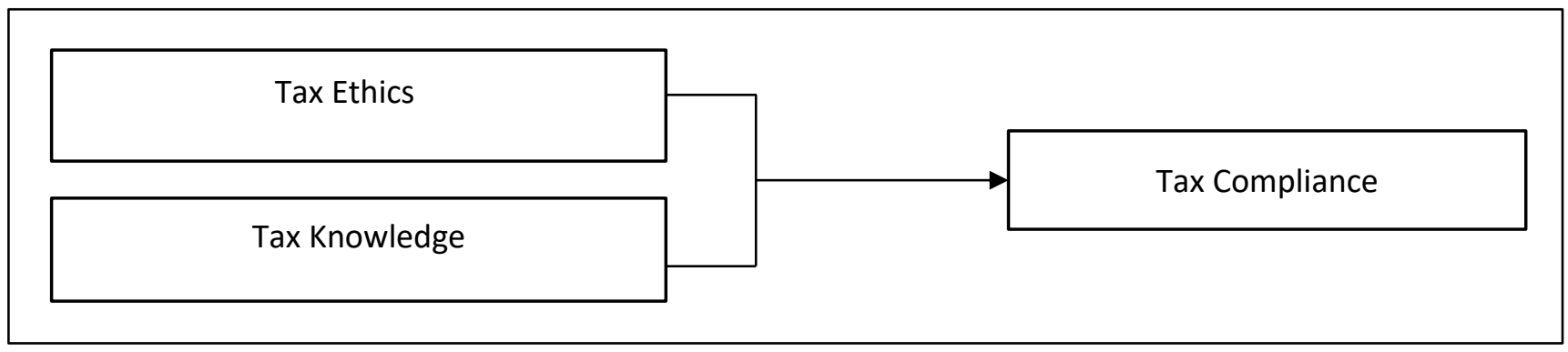

Figure 1: Research Model

\section{Implications}

The present study is of great importance in directing the Tax Authority towards increasing tax compliance among taxpayers in Palestine. This study recommends the need to target taxpayers by enriching the Palestinian curriculum with the importance of taxes and increasing the level of awareness and knowledge of students coming to their practical and economic lives. In addition to conducting training programs for those who wish to know more about tax laws and how to calculate and estimate them, all of this would increase tax awareness among taxpayers and increase tax compliance. Taxpayers are more likely to comply when they gain knowledge of tax laws, leading to a rise in the ethical level that positively affects society as a whole. When taxpayers pay the taxes due to them, the level of services and welfare will increase, and interest will prevail on all individuals in line with the saying that "the state develops when the public interest overwhelms personal interests." Tax compliance can also be encouraged by concluding agreements between countries in order to exchange assistance and experiences. 


\section{Conclusion}

The Palestinian government relies heavily on taxes as one of its sustainable sources of income. However, the challenge of non-compliance with taxation has diminished the government's ability to maximize the generation of projected tax revenues to finance development projects. There are many factors that affect tax compliance, whether economic or psychological factors, but this study examined only two important factors, namely ethics and tax knowledge. From the discussion of the previous literature on these factors, it was found that they are of great importance to compliance, but the relationship between them remains mixed and more studies are needed to verify this relationship.

\section{Acknowledgements}

The authors would like to thank Palestine Ahliya University for their continuous support in carrying out this work.

\section{References}

Abuamria, F. (2019). The Effect of Deterrence Factors on Discourage Shadow Economy Level and Tax Evasion. International Journal of Academic Research in Accounting, Finance and Management Sciences, 9(1), 62-67.

Al Zeer, I., Alkhatib, A. A., \& Alshrouf, M. (2019). Determinants of Organisational Commitment of Universities' Employees. International Journal of Academic Research in Accounting, Finance and Management Sciences, 9(1), 136-141.

Alkhatib, A, A., \& Abdul-Jabbar, H. (2017). An Economic Framework for Tax Evasion in Palestine. American-Eurasian Journal of Scientific Research, 12(6), 300-304.

Alkhatib, A. A., Abdul-Jabbar, H., Abuamria, F., \& Rahhal, A. (2019). The effects of social influence factors on income tax evasion among the palestinian SMEs. International Journal of Advanced Science and Technology, 28(17), 690-700.

Alkhatib, A. A., Abdul-jabbar, H., \& Marimuthu, M. (2018). The effects of deterrence factors on income tax evasion among Palestinian SMEs. International Journal of Academic Research in Accounting, Finance and Management Sciences, 8(4), 144-152.

Alleyne, P., \& Harris, T. (2017). Antecedents of taxpayers' intentions to engage in tax evasion: Evidence from Barbados. Journal of Financial Reporting and Accounting, 15(1), 2-21.

Alm, J., \& Torgler, B. (2011). Do ethics matter? Tax compliance and morality. Journal of Business Ethics, 101(4), 635-651.

Alshrouf, M. (2019). The effect of tax audit using the computer on tax non-compliance in Palestine. International Journal of Academic Research in Business and Social Sciences, 9(3), 296-304.

Ariel, B. (2012). Deterrence and moral persuasion effects on corporate tax compliance: Findings from a randomized controlled trial. American Society of Criminology, 50(1), 27-69.

Chan, C. W., Troutman, C. S., \& O'Bryan, D. (2000). An expanded model of taxpayer compliance: Empirical evidence from the United States and Hong Kong. Journal of International Accounting, Auditing and Taxation, 9(2), 83-103.

Coalition for Accountability and Integrity. (2018). USD 500 million losses of tax evasion in Palestine (in Arabic). Life Press. Retrieved from http://www.hayatweb.com/ breaking/143106 
Eriksen, K., \& Fallan, L. (1996). Tax knowledge and attitudes towards taxation; A report on a quasiexperiment. Journal of Economic Psychology, 17(3), 387-402.

Frey, B. S., \& Torgler, B. (2007). Tax morale and conditional cooperation. Journal of Comparative Economics, 35(1), 136-159.

Jaafar Harun, R., Abu Bakar, J. M., \& Mohd Tahir, I. (2011). Ethics on tax evasion: Do accounting and business students' opinions differ? International Business and Management, 2(1), 122128.

Kasper, M., Kogler, C., \& Kirchler, E. (2013). Tax policy and news: An empirical analysis of taxpayers' perception of tax related media coverage and its impact on tax compliance. (Working Paper, No. 2013-07). WU International Taxation Research, Vienna University of Economics and Business, Australia.

Kira, A. R. (2017). An evaluation of goverments' initiatives in enhancing small taxpayers' voluntary tax compliance in developing countries. International Journal of Academic Research in Accounting, Finance and Management Sciences, 7(1), 253-267.

Manual, V., \& Xin, A. Z. (2016). Impact of tax knowledge, tax compliance cost, tax deterrent tax measures towards tax compliance behavior: A survey on self-employed taxpayers in West Malaysia. Electronic Journal of Business and Management, 1(1), 56-70.

McGee, R. W., \& Tyler, M. (2006). Tax evasion and ethics: A demographic study of 33 countries. (Working Paper,)Andreas School of Business, Florida, USA.

Nhavira, J. D. G. (2016). A survey of attitudes to tax evasion by part-time business studies students at the University of Zimbabwe. The Science Probe, 4(1), 10-22.

Oladipupo, A. O., \& Obazee, U. (2016). Tax knowledge, penalties and tax compliance in small and medium scale enterprises in Nigeria. IBusiness, 8(1), 1-9.

Qubbaja, A., Omar, S. A. (2019). The Impact of Political Events on Palestine Securities Exchange Returns: An Empirical Study between (1997-2016), International Journal of Academic Research in Accounting, Finance and Management Sciences, 9(3), 287-294.

Riahi-Belkaoui, A. (2004). Relationship between tax compliance internationally and selected determinants of tax morale. Journal of International Accounting, Auditing and Taxation, 13(2), 135-143.

Slehat, Y. A. (2009). The tendency toward tax evasion in Jordan. (Unpulished Doctoral dissertation). Universiti Utara Malaysia, Sintok, Malaysia.

Torgler, B., \& Schneider, F. (2009). The impact of tax morale and institutional quality on the shadow economy. Journal of Economic Psychology, 30(2), 228-245. 